\title{
Hubungan antara Kecenderungan Internet Addiction dengan Empati pada Anak Sekolah Dasar
}

\author{
Galuh Mawarani ${ }^{1}$ \\ Fakultas Psikologi, Universitas Muhammadiyah Malang \\ e-mail: ' galuhmawarani13@gmail.com
}

\begin{abstract}
Empathy in children is considered very important because it will affect their social and individual skills. One of the factors that influences the empathy is communication through the internet. The tendency of internet addiction is the use of the internet which is aimed of accessing social media, playing online games, listening to music and videos online excessively. The purpose of this study is to determine the relationship between the tendency of internet addiction and empathy in elementary school children. This study used a correlational qualitative approach. The subjects were 115 students with a range of grades 4 to 6 taken by purposive sampling technique. The method of data analysis was the product moment correlation method from Karl Pearson of utilizing the SPSS 21.0 program. The results showed that ( $r$ ) mark was 0.206 with $p$ was $0.014<0.05$. It indicated that there is a significant negative relationship between the tendency of internet addiction and the empathy. The contribution of internet addiction to the empathy was $4,2 \%\left(r^{2}=0.042\right)$.
\end{abstract}

KEYWORDS Empathy, internet addiction tendency, elementary school students

CITATION Mawarani, G. (2019). Hubungan antara kecenderungan internet addiction dengan empati pada anak sekolah dasar. Cognicia, 7, (1), $1-15$.

Sekolah dasar merupakan masa dimana anak-anak mengalami perubahan dalam berelasi dengan lingkungannya, yaitu dengan orang tua, teman sebaya, maupun kehidupan di sekolahnya. Dalam hal ini sekolah memberikan kehidupan akademik yang baru dan berbeda dengan tingkatan sebelumnya, yaitu masa prasekolah. Dilihat dari konteks hubungan sosialnya, anak dengan rentang usia sekolah dasar, atau lebih khususnya untuk usia 8 hingga 12 tahun akan dihadapkan pada pengalamanpengalaman baru dan tuntutan untuk mengarahkan energinya dalam menguasai ketrampilan intelektual dan ketrampilan sosial (Santrock, 2011). Di masa ini pula anakanak cenderung mendeskripsikan diri mereka dengan karakteristik psikologis yang beraneka ragam. Menurut Harter (dalam Santrock, 2011) mereka mendeskripsikan dirinya sebagai anak yang "popular, baik, suka membantu, kejam, cerdas, dan bodoh". Anak dengan deskripsi diri "suka membantu" akan berusaha untuk menampilkan dirinya sebagai seorang anak yang mampu mengasumsikan perspektif anak lain serta mampu memahami pikiran dan perasaan anak lainnya pula dengan tujuan untuk menunjang identitas dirinya sebagi anak yang "suka membantu". Kemampuan untuk melakukan hal tersebut biasa disebut dengan perspective taking. Dalam hal ini, 
perspective taking bertujuan sebagi basis berkembangnya empati. Menurut (Scott \& Graham, 2015) empati merupakan suatu aspek kepribadian yang penting dan harus dipelajari oleh anak-anak untuk menunjang perilaku prososial atau perilaku membantu, altruisme, dan keterlibatan mereka dalam masyarakat sehingga mereka akan mendapatkan perkembangan masa anak yang maksimal. Istilah empati pertama kali diperkenalkan oleh Titchener pada tahun 1909 ke dalam Bahasa Inggris (empathy) yang sebelumnya masih dalam istilah Jerman yaitu "Einfühlung" (Titchener, 2014). Menurut Titchener (2014) empati dapat didefinisikan sebagai simpati yang penuh dimana seseorang akan berpikir setelah melihat obyek kemudian mengerti dan memahami obyek tersebut lalu akan berbicara dalam bahasa mereka. Dengan kata lain empati merupakan kemampuan seseorang sebagai observer untuk mengerti apa yang orang lain pikirkan dan rasakan dalam situasi yang diberikan lalu bertindak sesuai dengan pemahaman masing-masing individu tersebut. Selanjutnya menurut Zoll \& Enz (2010) empati dapat didefinisikan sebagai kemampuan dan kecenderungan seseorang (oberserver) untuk memahami apa yang orang lain (target) pikirkan dan rasakan dalam situasi tertentu.

Empati (Hoffman, 2000) juga merupakan keterampilan sosial yang mendasari pentingnya kemampuan dalam memainkan peran penting dalam perkembangan moral dan perilaku prososial. Sehingga ini penting untuk dimiliki oleh setiap individu di kehidupan sehari-hari. Dalam konteks pendidikan, empati didefinisikan sebagai kemampuan untuk berhubungan dengan perspektif atau perasaan orang lain. Tanpa empati, individu akan acuh tak acuh atau meremehkan orang lain dan mungkin terlibat dalam perilaku antisosial di lingkungannya. Empati memberikan sarana bagi individu untuk menjalani hidup yang penuh kasih sayang dan sadar sosial (Erickson \& Noonan, 2018). Empati dinilai penting untuk dikembangkan sejak dini khususnya untuk anak-anak. Adapun beberapa indikator seorang anak dapat disebut memiliki empati yang baik yaitu (1) menunjukkan kepekaan sosial atau memahami perasaan orang lain; (2) menunjukkan kepekaan terhadap kebutuhan dan perasaan orang lain; (3) memahami orang lain secara tepat dari sikap tubuh, bahasa tubuh, ekspresi wajah, dan nada suara; (4) memahami ekspresi yang ditunjukkan orang lain dan memberi reaksi yang tepat; (5) memahami kesedihan orang lain dan memberi respon yang tepat; (6) menunjukkan bahwa ia mengerti peraaan orang lain; (7) meneteskan air mata atau ikut bersedih ketika orang lain sedang bersusah hati; (8) menunjukkan kepedulian ketika orang lain diperlakukan tidak baik dan tidak adil; (9) menunjukkan keinginan untuk memahami sudut pandang orang lain; (9) mengungkapkan secara lisan pemahaman terhadap perasaan orang lain (Borba, 2008).

Terdapat dua macam komponen dalam empati, yaitu empati afektif dan empati kognitif (Zoll \& Enz, 2010). Lebih lanjut, komponen afektif empati ini berkaitan dengan proses di mana emosi dalam pengamat muncul karena kesadaran ataupun ketidaksadaran internal terhadap target, termasuk didalamnya emosi atau pikiran dan sikap. Berbeda dengan komponen afektif empati, komponen kognitif empati menangkap perbedaan proses kognitif dalam proses mengamati, mulai dari yang relatif sederhana yaitu pada proses hubungan sosial hingga pada tahap mengambil alih perspektif orang lain (Zoll \& Enz, 2010). 
Dengan mengembangkan empati sejak usia dini, diharapkan akan dapat meningkatkan ketrampilan sosial anak sehingga dapat berdampak positif dalam kehidupan sehari-hari termasuk peningkatan dalam prestasi akademik anak di sekolah (Howe, 2015). Selain itu diharapkan pula, dengan keterampilan sosial yang tinggi, individu mampu berperilaku dan berperan sesuai dengan norma sosial yang berlaku. Sesuai dengan penelitian yang telah dilakukan oleh Husni (2018) yang menyatakan bahwa pelatihan empati berpengaruh positif dan signifikan terhadap ketrampilan sosial pada bystander assistant bullying di SMP " $X$ " Yogyakarta. Namun dapat diketahui, pada masa kini, situasi kehidupan siswa sekolah dasar dinilai sudah menunjukkan atau mengarah pada rendahnya empati. Berdasarkan hasil observasi yang dilakukan oleh Destiyana (2016) di SDN Caturtunggal 3 Depok menyatakan bahwa gejala rendahnya empati ini tampak pada perilaku siswa di kelas yang menunjukkan sikap egosentris. Bahkan ada siswa yang tidak mau meminjamkan barangnya untuk siswa lainnya dan menyarankan untuk meminjam kepada siswa selain dirinya, tidak ada siswa yang menenangkan atau menghibur temannya ketika menangis karena diejek siswa lainnya, serta terdapat siswa yang mengungkapkan ekspresi tidak senang ketika siswa lainnya mendapatkan juara kelas. Hal ini didukung pula oleh penelitian yang telah di lakukan oleh Hadi Pranata (dalam Arniansyah, Nadhilla, Permatasari, Milani \& Putri, 2018) yang menyatakan bahwa di Indonesia telah terjadi penurunan kemampuan berempati sejak anak masih berusia dini. Selain itu, anak Indonesia masih memiliki empati yang rendah apabila dibandingkan dengan anak-anak dengan rentang usia yang sama di Jepang.

Menurut Hoffman (2000) adapun beberapa faktor yang mempengaruhi empati yaitu : (1) mood and feeling; (2) situasi dan tempat; (3) proses belajar dan identifikasi; (4) komunikasi dan bahasa; (5) pengasuhan; serta (6) sosialisasi. Dijelaskan lebih lanjut bahwa faktor mood and feeling merupakan situasi perasaan individu ketika proses interaksi berlangsung dengan lingkungannya yang akan mempengaruhi cara individu tersebut dalam memberikan respon terhadap perasaan dan perilaku orang lain. Kemudian pada faktor situasi dan tempat dijabarkan bahwa pada situasi tertentu individu dapat berempati lebih baik dibandingkan dengan situasi yang lain. Selanjutnya dalam faktor proses belajar dan identifikasi disebutkan bahwa apa yang telah dipelajari individu di rumah atau pada situasi tertentu diharapkan dapat diterapkan pula oleh individu tersebut pada lain waktu. Berikutnya dalam faktor komunikasi dan bahasa dijelaskan bahwa pengungkapan empati dipengaruhi oleh komunikasi atau bahasa yang digunakan seseorang. Dalam hal ini, perbedaan bahasa dan ketidakpahaman tentang komunikasi akan menjadi hambatan pada proses empati. Kemudian pada faktor pengasuhan dijelaskan bahwa lingkungan yang memiliki empati yang tinggi dari suatu keluarga sangat membantu anak dalam menumbuhkan empati dalam dirinya. Terakhir, pada faktor sosialisasi dijelaskan bahwa dengan adanya sosialisasi memungkinkan seseorang dapat mengalami sejumlah emosi, mengarahkan seseorang untuk melihat keadaan orang lain dan berpikir tentang orang lain.

Sesuai pernyataan diatas, salah satu faktor yang mempengaruhi empati menurut Hoffman (2000) adalah sosialisasi. Ketika proses sosialisasi berlangsung, siswa sekolah dasar mendapati lingkungan pergaulannya, khususnya di sekolahnya yaitu teman 
sebayanya. Dalam menjalani proses sosialisasi, siswa tidak akan terlepas dari proses komunikasi. Seiring berkembangnya jaman banyak anak usia sekolah dasar yang memanfaatkan penggunaan teknologi untuk menunjang proses sosialisasinya dengan individu lain di lingkungan sekitarnya. Individu-individu tersebut, termasuk kedua orang tua, teman sebaya, guru, maupun individu-individu lainnya yang berada di sekitar lingkungan sosial siswa. Penggunaan teknologi secara berlebihan diasumsikan akan berdampak negatif pada siswa, khususnya dalam memenuhi tugas perkembangannya dalam konteks kehidupan sosial mereka. Dalam menjalani kehidupan sosial, siswa seharusnya mampu bersosialisasi dengan individu lain dengan maksimal tanpa terhambat oleh aktivitas-aktivitas lain yang dapat berdampak negatif, termasuk didalamnya aktivitas terkait penggunaan teknologi. Namun seperti yang telah diketahui, seiring bergantinya zaman, pengetahuan dan teknologi pun semakin canggih dan menarik untuk digunakan khususnya bagi kalangan siswa sekolah dasar.

Salah satu teknologi yang sedang marak digunakan oleh siswa khususnya siswa sekolah dasar adalah gadget atau smartphone. Dengan menggunakan gadget atau smartphone mereka akan dengan mudah mengakses internet dan mencari segala sesuatu yang mereka inginkan, termasuk didalamnya game online, sosial media, menonton video, dan masih banyak lainnya. Rentang usia anak-anak dinilai lebih mengerti dan canggih dalam pengoperasian internet daripada orang dewasa (Candra, 2013). Penggunaan internet dinilai dapat berdampak buruk pula bagi perkembangan sosial anak apalagi jika tidak diberi pendampingan khusus oleh orang yang lebih dewasa. Mengingat bahwa hasil penelitian yng terdiri atas 31 negara dari tujuh wilayah dunia (Amerika Utara, Oseania, Eropa Utara dan Barat, Eropa Selatan dan Timur, Timur Tengah, Asia, dan Amerika Selatan) menyatakan bahwa 6\% pengguna internet dinyatakan mengalami internet addiction (Ginige, 2017). Selain itu Young (dalam Basri, 2014) yang menyatakan bahwa internet addiction menyerang masuk ke sekolah-sekolah, kantor-kantor, dan juga rumah-rumah. Sehingga dari beberapa pernyataan tersebut dapat diasumsikan bahwa setiap individu, termasuk anak-anak memiliki resiko tinggi untuk mengalami kecenderungan internet addiction.

Penelitian yang dilakukan oleh Khouli (2013) menyatakan bahwa di Arab penggunaan internet dinilai berdampak pada stabilitas keluarga utamanya anak-anak. Anak-anak dinilai yang paling sering menggunakan internet tanpa adanya bimbingan dan kontrol yang efektif. Berikutnya (Li, Zhang, Lu, Zhang, \& Wang, 2014) mengungkapkan bahwa terdapat 12.993 siswa SD dan SMP di Cina yang telah mengakses internet. Kemudian sebanyak 1.523 siswa diantaranya mengalami adiksi atau kecanduan internet. Fenomena internet addiction atau kecanduan internet pada anak-anak juga disebutkan oleh Pezoa-Jares, Espinoza-Luna, \& Vaquez-Medina (2012) yang menyatakan bahwa dari 563 pengguna intenet, anak-anak dan remaja lebih menunjukkan kecenderungan gejala internet addiction daripada orang dewasa. Selanjutnya berdasarkan penelitian yang dilakukan oleh Poli dan Agrimi (2012) menunjukkan bahwa prevalensi kecanduan internet pada pelajar di Italia dengan rentang usia 14 hingga 21 tahun mencapai angka 5,8\%. Di Indonesia, penelitian yang dilakukan oleh Candra (2013) juga mencantumkan data mengenai jumlah penggunaan internet pada anak-anak antara usia 6 sampai dengan 12 tahun di Surabaya, yang 
menunjukkan bahwa sekitar 12 anak yang berusia lima tahun sudah mengenal internet. Kemudian, penelitian lainnya dilakukan oleh Husni \& Fatulloh (2016) menyatakan bahwa sebanyak 1551 orang siswa kelompok SD dan SMP yang menjadi sampel penelitian sekitar $94,84 \%$ menyatakan pernah menggunakan internet. Sehingga fakta ini menunjukan bahwa penggunaan internet di kalangan pelajar di Indonesia sudah sangat tinggi.

Melihat penggunaan internet pada anak sekolah dasar sudah menjadi hal yang wajar, dimungkinkan pula bahwa pada siswa-siswa tertentu penggunaannya bisa saja dalam rentang waktu yang lama serta intensitas pemakaiannya yang sering dalam satu hari. Hal ini ditakutkan akan mengakibatkan anak lebih tertarik pada internet daripada kehidupan sosial yang seharusnya mereka jalani hingga mengarah kepada kecenderungan terhadap kecanduan internet atau internet addiction. Internet addiction atau adiksi terhadap internet dapat diartikan sebagai suatu ketidakmampuan individu untuk mengontrol atau kehilangan kontrol atas penggunaan internet, yang menyebabkan gejala ketergantungan psikologis, sosial, akademik dan beragam konsekuensi negatif lainnya pada individu (Brand, Young \& Laier, 2014). Adapun kriteria internet addiction menurut Young dan Abreu (2010) meliputi (1) merasa keasyikan dengan internet; (2) memerlukan waktu tambahan dalam mencapai kepuasan sewaktu menggunakan internet; (3) tidak mampu mengontrol, mengurangi, atau menghentikan penggunaan internet; (4) merasa gelisah, murung, depresi atau lekas marah ketika berusaha mengurangi atau menghentikan penggunaan internet; (5) mengakses internet lebih lama dari yang diharapkan; (6) kehilangan orang-orang terdekat, pekerjaan, kesempatan pendidikan atau karier gara-gara penggunaan internet; (7) membohongi keluarga, terapis, atau orang-orang terdekat untuk menyembunyikan keterlibatan lebih jauh dengan internet; (8) menggunakan internet sebagai jalan keluar mengatasi masalah atau menghilangkan perasaan seperti keadaan tidak berdaya, rasa bersalah, kegelisahan atau depresi.

Penelitian yang dilakukan oleh Puspitasari (2018) menyatakan bahwa dari 126 sampel siswa kelas 4 dan 5 di SD Muhammadiyah 1 Ponorogo dinyatakan sebesar 15,1\% siswa mengalami internet addiction dengan kategori sangat rendah; 56,3\% siswa mengalami internet addiction dengan kategori rendah; 26,2\% siswa mengalami internet addiction dengan kategori sedang; dan 2,4\% siswa mengalami internet addiction dengan kategori tinggi. Kemudian apabila siswa sudah terfokus terhadap internet dan lebih mementingkan internet dari pada teman sebayanya atau mengarah pada kecenderungan adiksi terhadap internet dimungkinkan akan berdampak pada perilaku pengabaian sosial dan rasa tidak peduli terhadap sesama pada siswa. Padahal melalui rasa peduli sosial dan berusaha untuk menggunakan internet sesuai dengan kebutuhan dan tidak mengabaikan saran durasi penggunaan internet sesuai dengan usia dimungkinkan akan mampu memperbaiki ketrampilan sosial individu dan akan berdampak positif pula untuk meningkatkan empati siswa.

Adapun beberapa tujuan penggunaan internet khususnya untuk anak-anak dengan rentang usia 10 hingga 14 tahun terbagi atas penggunaan sosial media, bermain game online, musik dan video online, dan penggunaan internet dalam konteks akademik (Lai \& Frascisco, 2016). Individu dengan kondisi kecenderungan internet addiction akan mengabaikan hubungan sosial dengan teman-teman, rekan kerja, dan 
dengan komunitas mereka. Ketika kecanduan tumbuh dan tidak diberi penanganan, mereka akan menjadi terbiasa dengan aktivitas internet, mereka akan lebih memilih game online, mengobrol dengan teman-teman online, dan secara bertahap mengabaikan keluarga dan teman-temannya dan lebih memilih menghabiskan waktunya untuk mengakses internet (Shahnaz, 2014).

Dalam laman republika.co.id (Ramadhani, 2017) disebutkan bahwa melalui cara mematikan akses internet dan menyimpan ponsel saat sedang berbicara dengan orang lain merupakan cara yang cukup efektif untuk tetap bisa bersosialisasi dengan orang lain. Hal tersebut dinilai akan berdampak positif ketika diterapkan mengingat bahwa dampak internet dinilai dapat menurunkan ketrampilan sosial. Hal ini sesuai dengan penelitian yang dilakukan oleh Lachmann dkk (2018) yang menyatakan bahwa penggunaan internet dalam smartphone yang lebih tinggi secara signifikan berpengaruh pada skor personal distress yang lebih tinggi pula. Penelitian berikutnya yang dilakukan oleh Jiao, Wang, Peng \& Cui (2017) menyatakan bahwa penggunaan internet mengakibatkan penurunan kepekaan terhadap rasa sakit yang diderita oleh orang lain. Bahkan penggunaan internet juga menunjukkan efek pengurangan terhadap perasaan afektif dan emosi untuk saling berbagi sebagaimana mestinya untuk memberikan perhatian terhadap orang lain yang sedang menderita kesakitan. Riset yang dilakukan Wang, Ge, Zhang, Liu \& Luo (2014) dengan menggunakan subjek anak-anak Sekolah Menengah Pertama diperkotaan menemukan bahwa individu yang kecanduan internet memiliki waktu reaksi yang lebih lama dan akurasi yang lebih rendah ketika menilai gambar rasa sakit dan bukan rasa sakit dibandingkan dengan kelompok yang tidak kecanduan internet. Beberapa penelitian terdahulu menunjukkan bahwa efek atau akibat penggunaan internet berdampak negatif terhadap ketrampilan sosial siswa yang mengarah pada tingkat empati siswa. Hal ini dipertegas pula oleh penelitian yang dilakukan Mazuritsky (2016) bahwa penggunaan internet secara kompulsif berhubungan negatif dengan perilaku altruisme dan empati. Selanjutnya Melchers, Li, Chen, Zhang \& Montag (2015) dalam penelitiannya juga menyebutkan bahwa terdapat hubungan yang signifikan antara empati yang rendah dengan permasalahan dalam penggunaan internet di Negara Cina dan Jerman. Sehingga terdapat kemungkinan bahwa empati akan rendah apabila siswa sekolah dasar menggunakan internet dengan intensitas yang sering dan lama. Padahal dengan empati yang tinggi dinilai dapat memprediksi individu untuk lebih prososial, memiliki perspective taking yang tinggi, serta memiliki simpati yang tinggi pula. Lebih tepatnya, tugas perkembangan siswa sekolah dasar dalam hal ketrampilan sosial akan lebih terpenuhi.

Sebaliknya apabila empati rendah, maka individu akan cenderung mengembangkan sikap anti sosial dan memunculkan sikap egosentris, serta kurang peduli terhadap lingkungan sosialnya termasuk didalamnya perilaku agresif dan bullying. Sehingga hal tersebut akan menghambat proses sosial pada siswa di lingkungan sekolah. Hal ini sesuai dengan penelitian yang dilakukan oleh Arpaci, Kesici \& Baloglu (2017) yang menyatakan bahwa siswa yang merasa lebih nyaman dalam menggunakan internet, maka mereka akan mengembangkan sikap individualisme atau berperilaku lebih ke arah kepentingan pribadi mereka sendiri. Mereka lebih menekankan dalam hal berbagi emosi atau perasaan mereka dan membentuk kedekatan atau ikatan dalam hubungan yang terbatas dalam lingkungan 
sosialnya. Siswa dengan karakteristik tersebut dimungkinkan akan mengalami kesulitan dalam membentuk hubungan sosial secara langsung atau tatap muka. Lebih lanjut, salah satu alasan siswa menggunakan internet yaitu dikarenakan siswa tersebut tidak dapat memenuhi kebutuhan psikologis mereka dalam hubungan tatap muka sehingga mereka akan mencari kepuasan dalam konteks lain yaitu internet ( $\mathrm{Li}, \mathrm{Zhang}$, Lu, Zhang, \& Wang, 2014). Hal ini jika dilakukan secara terus menerus dikhawatirkan akan menyebabkan kecanduan atau adiksi siswa terhadap intenet yang tentunya sangat merugikan bagi diri siswa tersebut.

Kecanduan internet juga dapat menyebabkan masalah kesehatan fisik dan psikologis anak-anak dan remaja, seperti depresi dan keinginan untuk bunuh diri, kesepian, masalah interpersonal, masalah manajemen waktu, sulit tidur, dan gaya hidup yang destruktif. Adapun kemungkinan yang lebih besar yaitu individu akan berperilaku agresif dan bahkan melakukan kejahatan jika individu kecanduan internet (Li, Zhang, Lu, Zhang, \& Wang, 2014). Sementara dalam hal fisik, internet dapat menyebabkan kerusakan retina mata dan menyebabkan kelelahan atau disfungsi organ tubuh tertentu (Saefulloh, 2018).

\section{METODE}

Penelitian ini menggunakan pendekatan kuantitatif. Desain penelitian yang digunakan dalam penelitian ini adalah korelasional. Pengambilan sampel dalam penelitian ini menggunakan teknik non-probability sampling. Pendekatan yang digunakan dalam teknik ini yaitu pendekatan purposive sampling yaitu responden yang terpilih menjadi anggota sampel merupakan hasil pertimbangan dari peneliti (Darmawan, 2014). Pertimbangan yang dimaksud oleh peneliti adalah berdasarkan pada syarat dan ketentuan yang telah dibuat sebelumnya, yaitu : 1) siswa sekolah dasar yang merupakan siswa kelas 4, 5, dan 6 sekolah dasar; 2) memiliki handphone, laptop ataupun komputer pribadi; 3) pernah menggunakan internet dan menggunakannya secara aktif. Pengguna internet secara aktif adalah orang yang menggunakan internet pada kurun waktu satu bulan terakhir, baik yang sudah terbiasa menggunakan internet maupun masih baru menggunakan internet (Emmanoulides \& Hammond, 2000).

Jumlah sampel dalam penelitian ini adalah sebanyak 115 siswa di SDN 1 Campurdarat Tulungagung. Selanjutnya adapun alasan peneliti menggunakan kriteria subjek hanya pada siswa sekolah dasar pada tingkat kelas empat hingga enam saja karena berdasarkan pernyataan Sari, Matiaz, \&Yunus (2014) menyatakan bahwa siswa dinilai sudah mampu memahami teks panjang dan memaknai kalimat dimulai pada tingkat kelas empat sekolah dasar.

Pada penelitian ini terdapat dua variabel yakni variabel bebas $(X)$ dan variabel terikat $(\mathrm{Y})$. Adapun yang menjadi variabel bebas $(\mathrm{X})$ adalah kecenderungan internet addiction dan variabel terikat $(\mathrm{Y})$ adalah empati. Kecenderungan internet addiction yang peneliti maksud adalah penggunaan internet secara aktif dengan tujuan untuk mengakses sosial media, bermain game online, musik dan video online secara berlebihan. Instrumen penelitian menggunakan skala Young-Internet Addiction Diagnostic Questionnaire yang disusun oleh Young (2016) yang berjumlah 8 item dan dikembangkan oleh peneliti berdasarkan 8 kriteria internet addiction. 
Empati yang peneliti maksud adalah kemampuan siswa sekolah dasar untuk mencoba mengenal, merasakan dan memahami kondisi orang lain dalam suatu situasi dengan ungkapan verbal maupun nonverbal serta mampu mengkomunikasikannya kepada orang lain. Dalam hal ini, empati diukur dengan alat ukur Questionnaire to Assess Affective and Cognitive Empathy in Children yang disusun oleh Zoll \& Enz (2010) yang berjumlah 28 item. Alat ukur ini juga diadaptasi oleh peneliti dengan mengacu pada dua aspek dalam empati yang telah disebutkan sebelumnya. Kedua alat ukur dalam penelitian ini menggunakan skala Likert. Pada skala kecenderungan internet addiction pada setiap item dalam kelompok pernyataannya mempunyai dua pilihan jawaban yaitu: Ya dan Tidak. Selanjutnya pada skala empati pada setiap item dalam kelompok pernyataannya mempunyai lima pilihan jawaban yaitu: Sangat Tidak Setuju, Tidak Setuju, Kurang Setuju, Setuju, dan Sangat Setuju.

Berdasarkan uji validitas dan reliabilitas hasil tryout yang telah dilakukan terhadap 60 subjek anak sekolah dasar pada tingkat kelas 4 hingga 6 di Kota Malang dan Tulungagung menunjukkan bahwa alat ukur internet addiction memiliki jumlah item valid sebanyak 20 item dari 31 item yang telah dilakukan uji coba. Selanjutnya alat ukur kecenderungan internet addiction memiliki indeks validitas yang berkisar antara 0,329 - 0,668 dengan indeks reliabilitas sebesar 0,880. Berikutnya alat ukur empati memiliki jumlah item valid sebanyak 23 item dari 28 item yang telah dilakukan uji coba. Selanjutnya alat ukur empati memiliki indeks validitas yang berkisar antara 0,325 - 0,730 dengan indeks reliabilitas sebesar 0,903. Baik alat ukur internet addiction maupun alat ukur empati keduanya dinyatakan reliabel karena memiliki indeks reliabilitas atau nilai Croanbach Alpha diatas 0,60 (Azwar, 2013).

\section{HASIL}

Subjek dalam penelitian ini adalah siswa sekolah dasar pada rentang kelas 4 hingga 6 SD yang memiliki gadget pribadi (handphone, laptop, tablet, komputer, dan sejenisnya) serta menggunakan internet secara aktif. Total subjek dalam penelitian ini adalah sebanyak 115 siswa dengan kriteria yang sesuai. Adapun datanya sebagai berikut :

Tabel 1. Deskripsi Subjek Penelitian

\begin{tabular}{llcc}
\hline \multicolumn{2}{c}{ Kategori Demografis } & Frekuensi & Prosentase \\
\hline Jenis Kelamin & & & \\
& Laki-laki & 49 & $42,6 \%$ \\
& Perempuan & 66 & $57,4 \%$ \\
\hline Total & & & $100 \%$ \\
\hline Kelas & 4 & & \\
& 5 & 34 & $29,6 \%$ \\
& 6 & 30 & $26,1 \%$ \\
& & 51 & $44,3 \%$ \\
\hline Total & & & $100 \%$ \\
\hline
\end{tabular}


Mengacu pada tabel 1 dapat diketahui bahwa jumlah subjek yang berjenis kelamin laki-laki lebih sedikit daripada subjek dengan jenis kelamin perempuan. Jumlah subjek perempuan yaitu sebanyak 66 siswa atau sebesar 57,4 \% sedangkan jumlah subjek laki-laki yaitu 49 siswa atau sebesar 42,6\%. Selanjutnya subjek yang sedang duduk di kelas 4 sekolah dasar berjumlah 34 siswa atau sebesar 29,6\%, subjek yang sedang duduk di kelas 5 sekolah dasar berjumlah 30 siswa atau sebesar 26,1\%, dan subjek yang sedang duduk di kelas 6 sekolah dasar berjumlah 51 siswa atau sebesar $44,3 \%$.

Hasil menunjukkan bahwa jumlah subjek dengan kategori tinggi terhadap kecenderungan internet addiction sebanyak 54 siswa atau sebesar 46,9\%. Sedangkan jumlah subjek dengan kategori rendah terhadap kecenderungan internet addiction sebanyak 61 siswa atau sebesar 53,1\%. Sehingga dapat diketahui bahwa subjek dengan kategori kecenderungan internet addiction rendah lebih banyak daripada subjek dengan kategori kecenderungan internet addiction tinggi. Selanjutnya, didapatkan pula hasil yang menunjukkan bahwa jumlah subjek dengan kategori tinggi terhadap empati sebanyak 61 siswa atau sebesar 53,1\%. Sedangkan jumlah subjek dengan kategori rendah terhadap empati sebanyak 54 siswa atau sebesar $46,9 \%$. Sehingga dapat diketahui bahwa subjek dengan kategori empati tinggi lebih banyak daripada subjek dengan kategori empati rendah.

Skor yang paling tinggi dalam internet addiction adalah pada aspek merasa keasyikan dengan internet apabila dibandingkan dengan aspek-aspek lainnya, yaitu memperoleh skor sebesar 18,73\% dari sebanyak 115 subjek yang diteliti. Berdasarkan hasil analisa data terhadap 115 subjek dengan menggunakan metode korelasi product moment pearson dari Karl Pearson, diperoleh koefisien korelasi (r) sebesar -0,206 dengan nilai signifikansi $(p)$ sebesar 0,014 $<0,05$. Hasil ini menunjukkan bahwa terdapat hubungan negatif antara kecenderungan internet addiction dengan empati. Artinya semakin tinggi kecenderungan internet addiction yang dialami oleh siswa sekolah dasar maka semakin rendah pula empati yang dimilikinya, sebaliknya semakin rendah kecenderungan internet addiction yang dialami oleh siswa sekolah dasar maka semakin tinggi pula empati yang dimilikinya. Selanjutnya, mengacu pada hasil analisis data diperoleh nilai koefisien determinasi $\left(\mathrm{r}^{2}\right)$ sebesar 0,042 . Hal ini dapat diartikan bahwa sumbangan efektif dari kecenderungan internet addiction terhadap empati sebesar 4,2\% dan sisanya, yaitu sebesar 95,8 \% ditentukan atau dipengaruhi oleh variabel lain.

\section{DISKUSI}

Berdasarkan penelitian yang telah dilakukan, dapat diketahui bahwa terdapat hubungan negatif yang signifikan antara kecenderungan internet addiction dengan empati pada siswa sekolah dasar di SDN 1 Campurdarat Tulungagung. Hal ini didasarkan dari hasil analisa dengan menggunakan uji korelasi product moment pearson, yang menghasilkan nilai koefisien korelasi ( $r$ ) sebesar -0,206 dengan nilai $p$ sebesar $0,014<0,05$. Hal ini dapat dimaknai bahwa semakin tinggi kecenderungan internet addiction yang dialami oleh siswa sekolah dasar maka semakin rendah pula empati yang dimilikinya, sebaliknya semakin rendah kecenderungan internet addiction yang dialami oleh siswa sekolah dasar maka semakin tinggi pula empati yang dimilikinya. Hal ini sesuai dengan hipotesis yang telah diajukan oleh peneliti. 
Kecenderungan internet addiction memiliki hubungan atau korelasi kearah negatif dengan empati, dimana kecenderungan internet addiction merupakan suatu ketidakmampuan individu untuk mengontrol atau kehilangan kontrol atas penggunaan internet, yang menyebabkan gejala ketergantungan psikologis, sosial, akademik dan beragam konsekuensi negatif lainnya pada individu (Brand, Young \& Laier, 2014). Hal ini berbanding terbalik dengan empati yang cenderung mengarah pada kemampuan dan kecenderungan seseorang untuk memahami apa yang orang lain pikirkan dan rasakan dalam situasi tertentu (Zoll \& Enz, 2010).

Keadaan dimana kecenderungan internet addiction berhubungan negatif dengan empati ini dapat disebabkan oleh beberapa hal, dimana salah satunya yaitu melalui proses sosialisasi. Siswa sekolah dasar dalam menjalani kehidupan sosialnya, tentu tidak terlepas dari proses sosialisasi. Dimana proses sosialisasi sangat erat kaitannya dengan lingkungan pergaulan individu (Hoffman, 2000). Hal ini dikarenakan seorang individu memiliki dorongan kuat untuk bersama dan diterima oleh teman sebaya atau kelompoknya, sehingga mereka akan lebih mengikuti aturan yang dibuat oleh kelompok daripada aturan dalam keluarga (Hurlock, dalam Taufik, 2012). Lebih lanjut lagi dalam menjalani proses sosialisasi seseorang tidak akan terlepas dari penggunaan bahasa dan komunikasi. Sehingga dengan kata lain, komunikasi sangat penting digunakan dalam lingkungan pergaulan individu.

Seiring berkembangannya zaman banyak anak usia sekolah dasar yang berkomunikasi atau berinteraksi dengan teman sebayanya menggunakan alat komunikasi seperti smartphone dan lebih khususnya menggunakan internet sebagai medianya. Penggunaan internet secara berlebihan dapat diindikasikan kedalam kecenderungan internet addiction. Menurut Young (2016) internet addiction juga dapat mempengaruhi beberapa hal meliputi karakteristik internal, personality, sosial, dan keluarga. Dalam aspek sosial inilah individu yang mengalami kecenderungan internet addiction akan lebih mengembangkan ketidakpedulian terhadap lingkungan sosialnya. Hal ini sesuai dengan pernyataan Pebriana (2017) yang menyatakan bahwa anak dengan kecenderungan internet addiction akan merasa canggung dengan lingkungan pergaulannya karena berkurangnya interaksi sosial dengan teman sebaya serta anak akan menjadi kurang peka terhadap lingkungannya.

Berdasarkan penelitian yang telah dilaksanakan, sebanyak $46,9 \%$ subjek memiliki skor kecenderungan internet addiction yang tinggi, sedangkan sisanya atau sebesar 53,1\% memiliki skor yang rendah dari total subjek sebanyak 115 siswa. Berdasarkan hasil survei yang telah dilakukan oleh peneliti adapun beberapa hal yang dilakukan oleh anak-anak di SDN 1 Campurdarat ketika menggunakan internet yaitu untuk mengakses Youtube, game online, dan sosial media berupa aplikasi chatting Whatsapp. Hal ini sesuai dengan pernyataan Setyawan dan Sulistyono (2017) yang menyatakan bahwa banyak siswa yang menggunakan internet tidak untuk menyelesaikan tugas akademik, sebagaimana mestinya, namun untuk melakukan hal-hal yang lain, misalnya untuk membuka facebook, instagram, dan game online secara berlebihan.

Salah satu hal yang paling mempengaruhi kecenderungan internet addiction adalah neurotisme (Dong, Jiangyang, Xuelong, \& Hui, 2012). Kuss, Griffiths \& Binder (2013) juga menjelaskan bahwa neurotisme dalam hal ini berkaitan terhadap kecemasan, kemarahan, depresi, self-consciousness, perilaku impulsif, dan kerentanan 
psikologis yang dialami seseorang ketika berusaha mengurangi penggunaan internet. Namun hal ini berbeda dengan hasil penelitian yang telah dilakukan peneliti, dimana aspek yang memiliki skor paling tinggi adalah merasa keasyikan dengan internet, yaitu dengan prosentase $18,73 \%$. Hal ini sesuai dengan pernyataan $\mathrm{Li}$, Zhang, Lu, Zhang, \& Wang (2014) bahwa bagi siswa sekolah, internet menarik karena terdapat permainan dalam internet yang dapat memuaskan kebutuhan akan pemenuhan dirinya. Selain itu internet juga menyediakan komunikasi yang dapat menggantikan komunikasi yang tidak memadai di dunia nyata, dimana melalui internet siswa bertujuan untuk mendapatkan dukungan sosial dari pengguna internet lainnya serta dapat meningkatkan harga dirinya.

Berdasarkan penelitian yang telah dilaksanakan, dapat diketahui bahwa sebanyak 53,1\% siswa memiliki skor empati dengan kategori tinggi, kemudian sisanya sebanyak 46,9\% siswa memiliki skor empati dengan kategori rendah. Sehingga dapat diketahui bahwa subjek dengan kategori empati tinggi lebih banyak daripada subjek dengan kategori empati rendah. Sedangkan berdasarkan literatur yang peneliti sebutkan sebelumnya, kalangan siswa sekolah dasar di SDN Caturtunggal 3 Depok sudah mengalami gejala rendahnya empati, yang ditunjukkan oleh perilaku siswasiswanya di kelas yang menunjukkan sikap egosentris. Adapun beberapa hal yang menyebabkan terjadinya perbedaan ini, yaitu salah satunya perbedaan budaya tempat tinggal. Sesuai dengan pernyataan Hoffman (2000) yang menyatakan bahwa tempat juga merupakan salah satu faktor yang mempengaruhi empati pada individu. Dengan demikian dapat diketahui bahwa tempat penelitian yang dilakukan peneliti berada di daerah pedesaan, yaitu di SDN 1 Campurdarat Tulungagung, sedangkan literatur sebelumnya melakukan penelitian pada daerah perkotaan, yaitu di SDN Caturtunggal 3 Depok. Hal ini didukung pula oleh pernyataan Gustini (2017) yang menyatakan bahwa empati kultural individu yang berasal dari desa lebih tinggi dibandingkan dengan individu yang berasal dari kota.

Berikutnya, peneliti juga mendapatkan temuan berupa perbedaan skor kecenderungan internet addiction dan empati berdasarkan jenis kelamin. Sebanyak 115 subjek yang telah diteliti dengan jumlah laki-laki sebanyak 49 siswa dan perempuan berjumlah 66 siswa, hasil penelitian menunjukkan bahwa skor kecenderungan internet addiction laki-laki lebih tinggi dibandingkan skor perempuan, yaitu sebesar 55,1\%. Hal ini sesuai dengan penelitian yang telah dilakukan oleh Li, Zhang, Lu, Zhang, \& Wang (2014) yang menemukan bahwa lebih banyak laki-laki yang mengalami kecanduan internet daripada perempuan. Tahiroglu, Gonca, Mehtap, Neslihan, \& Ayse (2008) juga menyatakan bahwa perbedaan gender dalam kecanduan internet dapat dijelaskan oleh tingkat kontrol diri laki-laki yang lebih rendah dibandingkan dengan perempuan, selanjutnya laki-laki juga lebih banyak memiliki kemungkinan untuk memainkan game di internet daripada perempuan.

Kemudian, hasil penelitian juga menunjukkan bahwa skor empati laki-laki lebih rendah dibandingkan skor empati perempuan, dimana skor empati perempuan sebesar 59,1\%. Hal ini sesuai dengan penelitian sebelumnya yang dilakukan oleh Graaff, Minet, Susan \& Wim (2014) yang menyatakan bahwa empati relatif konsisten kuat atau tinggi pada jenis kelamin perempuan antara awal dan pertengahan masa remaja daripada laki-laki. Lebih lanjut lagi, Silberman dan Snarey (dalam Graff, 
Gustavo, Elisabetta, Hans \& Susan, 2018) menyebutkan bahwa di awal masa remaja, anak perempuan memiliki sebuah kualitas penguatan yang lebih baik daripada lakilaki dibidang intelektual dan fungsi kognitif sosial sampai pertengahan masa remaja.

Hasil penelitian mengenai adanya hubungan negatif antara kecenderungan internet addiction dengan empati didukung pula oleh beberapa penelitian sebelumnya, salah satunya yaitu penelitian yang dilakukan oleh Jeon \& Jee (2018) yang menyatakan empati terkait berhubungan negatif secara signifikan dengan waktu penggunaan internet dan jumlah teman dekat di internet. Penelitian selanjutnya yang mendukung hasil penelitian ini adalah penelitian yang dilakukan oleh Shin \& Dohyun (2013) yang melaporkan bahwa penggunaan game online mengurangi tingkat empati kognitif individu. Dalam hal ini ia juga menjelaskan bahwa anak-anak dan remaja lebih rentan terhadap pengaruh media daripada orang dewasa. Penggunaan game yang terlalu berlebihan juga akan menyebabkan ketidakaktifan kognitif sosial yang akan terjadi terus menerus. Padahal masa remaja adalah periode yang baik untuk pengembangan kognitif sosial. Dengan demikian, tidak aktifnya kognitif sosial selama periode ini dapat mengakibatkan keterlambatan pengembangan kemampuan sosial, khususnya empati kognitif.

Berdasarkan analisa yang telah dilakukan, peneliti menemukan bahwa sumbangan variabel kecenderungan internet addiction terhadap empati adalah sebesar $4,2 \%$, sehingga terdapat $95,8 \%$ faktor lain yag mempengaruhi empati. Sumbangan ini termasuk dalam kategori sangat rendah (Sugiyono, 2015). Literatur lain juga menyebutkan bahwa empati dipengaruhi oleh beberapa faktor, diantaranya yaitu (1) mood and feeling; (2) situasi dan tempat; (3) proses belajar dan identifikasi; (4) komunikasi dan bahasa; (5) pengasuhan; serta (6) sosialisasi (Hoffman, 2000). Dalam hal ini internet addiction dapat menjadi salah satu akibat dari proses komunikasi yang digunakan oleh siswa sekolah dalam berinteraksi dan bersosialisasi dengan individu lain. Adapun faktor lain yang mempengaruhi rendahnya empati pada individu yaitu agresi (Wang, Li, Jiping, Ling \& Fengqing, 2016) dan bullying (Noorden, Gerbert, Antonius \& William, 2014).

Adapun beberapa kelemahan pada penelitian ini yaitu penelitian ini hanya berfokus pada tujuan untuk mengetahui korelasi atau hubungan antara kecenderungan internet addiction dengan empati saja, tanpa mampu memperkirakan sebab akibat terjadinya hubungan antar dua variabel tersebut. Selanjutnya diperlukan pula perluasan jumlah subjek penelitian serta penambahan karakteristik yang berbeda sehingga diharapkan penelitian selanjutnya akan bersifat lebih general dan representatif.

\section{SIMPULAN DAN IMPLIKASI}

Berdasarkan hasil penelitian yang dilakukan dapat disimpulkan bahwa hipotesis diterima atau terdapat hubungan negatif antara kecenderungan internet addiction dengan empati pada anak sekolah dasar. Hal ini berarti semakin tinggi kecenderungan internet addiction yang dimiliki oleh anak sekolah maka semakin rendah empati yang dimilikinya, sebaliknya semakin rendah kecenderungan internet addiction yang dimiliki anak sekolah dasar maka semakin tinggi empati yang dimilikinya. 
Adapun implikasi dari penelitian ini yaitu : 1) Mengingat bahwa empati merupakan salah satu aspek kepribadian yang penting bagi manusia, diharapkan siswa mampu mengembangkan rasa empati dengan melakukan interaksi dan sosialisasi secara langsung di lingkungan sosial serta mulai sedikit demi sedikit belajar untuk tidak menjadikan internet sebagai prioritas; 2) Bagi orang tua dan guru, diharapkan memberikan pengarahan kepada siswa untuk menggunakan internet secara wajar, mengawasi aktivitas mereka ketika menggunakan internet, serta memberi batasan waktu yang digunakan siswa untuk mengakses internet; 3) Bagi pihak sekolah diharapkan sekolah juga memberikan sarana edukasi kepada siswa mengenai pengaruh-pengaruh internet serta pentingnya empati; 4) Bagi peneliti selanjutnya, diharapkan menambah variabel lainnya yang belum pernah diteliti ataupun mengganti dengan variabel lainnya, seperti kontrol diri, prokrastinasi, dan regulasi emosi. Kemudian untuk peneliti selanjutnya juga disarankan untuk menggunakan alat ukur yang lebih tepat khususnya untuk mengukur kecenderungan internet addiction serta menambahkan beberapa kriteria yang lebih mengerucut pada kecenderungan internet addiction untuk siswa yang akan dijadikan subjek penelitian. Selain itu diharapkan peneliti selanjutnya, mampu memberikan laporan mengenai bagaimana cara memaksimalkan efek positif dan meminimalkan efek negatif dari internet pada tingkat sekolah dasar sehingga dapat meningkatkan empati pada siswa.

\section{REFERENSI}

Arniansyah, N. N., Ratih E. P., Thalia M., Yuzi W. A. P. (2018). Pelatihan empati dan perilaku prososial pada anak usia 6-12 tahun di RPTRA anggrek Bintaro. Jurnal Muara Ilmu Sosial, Humaniora, dan Seni, 02, (01), 432-439.

Arpaci, I., Sahin K., Mustafa B. (2017). Individualism and internet addiction: the mediating role of psychological needs. Internet Research, 28 (02), 293-314.

Azwar, S. (2013). Metode penelitian. Yogyakarta: Pustaka Pelajar.

Basri, Said H. (2014). Kecenderungan internet addiction disorder mahasiswa fakultas dakwah dan komunikasi ditinjau dari religiousitas. Jurnal Dakwah, 15, (2), 407-432.

Brand, Matthias, Kimberly S. Y., Christian L. (2014). Prefrontal control and internet addiction : a theoritical model and review of neuropshychological and neuroimaging findings. Frontiers in Human Neuroscience, 8, (375), 1-13.

Borba, Michele. (2008). Membangun kecerdasan moral. Jakarta: PT Gramedia Pustaka Utama.

Bozoglan, B. (2017). Psychologycal, social, and culture aspects of internet addiction. United States of America: IGI Global.

Candra, P. A. (2013). Penggunaan internet pada anak-anak sekolah usia 6-12 Tahun di Surabaya. Commonline, 01, (02), 1-15.

Darmawan, D. (2014). Metode penelitian kuantitatif. Bandung: PT Remaja Posdakarya.

Destiyana. (2016). Upaya meningkatkan sikap empati melalui metode storytelling pada siswa SD negeri Caturtunggal 3 Depok. E-Journal Bimbingan dan Konseling, 09, 247-256.

Dong, G., Jiangyang W., Xuelong Y., Hui Z. (2012). Risk personality traits of internet addiction: a longitudinal study of internet-addicted chinese university students. Original Article Asia-Pacific Psychiatry, 1-6.

Emmanouilids, C, \& Kathy H. (2000). Internet usage: predictors of active users and frequency of use. Journal of Interactive Marketing, 14, (02), 17-32.

Erickson, G. \& Patricia N. (2018). Elementary teacher guide (grade pre-k-5) college and career competence:empathy. College and career competency, 1-7. 
Ginige, Pabasari. (2017). Internet Addiction Disorder. Child and Adolescent Mental Health, 141-163

Graff, J. V., Gustavo C., Elisabetta C., Hans M. K., Susan B. (2018). Prosocial behavior in adolescence: gender differences in development and links with empathy. Journal of Youth and Adolescence. 47, (05), 1-14.

Graff, J. V., Minet W., Susan J. T. B., Wim H. J. M. (2014). Perspective taking and empathic concern in adolescence: gender differences in developmental changes. Developmental Psychology, 50, (03), 881-888.

Gustini, N. (2017). Empati kultural pada mahasiswa. Journal od Multicultural Studies in Guidance and Counselig, 1, (01), 17-34

Hoffman, M. L. (2000). Empathy and moral development: implication for caring and justice. Cambridge. Cambridge University press.

Howe, D. (2015). Empati makna dan pentingnya. Yogyakarta: Pustaka Pelajar.

Husni, E. M. \& Agus F. (2016). Kategorisasi pengguna internet di kalangan pelajar SD dan SMP menggunakan metode Twostep Cluster. Seminar Nasional Aplikasi Teknologi Informasi, 6-16.

Husni, M. A. (2018). Efektivitas pelatihan empati untuk meningkatkan keterampilan sosial pada Bystander dalam peristiwa bullying di SMP " $X$ " Yogyakarta. Thesis, Program Pascasarjana Universitas Islam Indonesia, Yogyakarta.

Jares, R. E. P., Isabel L. E. L., Josue A. V. M. (2012). Internet addiction: a review. Journal of Addiction Research and Therapy, 1-10.

Jeon, H. J. \& Jee H. H. (2018). Is internet overuse associated with impaired emphatic ability in Korean college students ?. Observational Study. 97, (39), 1-5.

Jiao, C., Ting W., Xiaozhe P., Fang C. (2017). Impaired empathy processing in individuals with internet addiction disorder: an event-related potential study. Frontires in Human Neuroscience, 11, 1-10.

Khouli, M. E. (2013). The most important negative aspects of using social networking affecting the family stability in Abu Dhabi - a pilot study. IACSIT International Journal of Engineering \& Technology, (1), 85-90.

Kuss, D. J., Mark D. G., Jens F. B. (2013). Internet addiction in students: prevalence and risk factors. Computers in Human Behavior, 29, (3), 959-966.

Lachmann, B., Cornelia S., Raina Y. S., Ruixue L., Martin C. M., Benjamin B., Andrew J. C., Christian M. (2018). The role of empathy and life satisfaction in internet and smartphone use disorder. Frontiers in Psychology, 09, 1-11.

Lai, \& Francisco T. (2016). Sosioeconemic influence on adolescent problematic internet use through school-related psychosocial factors and pattern of internet use. Thesis, The Education University of Hong Kong, Hong Kong.

Li, Y., Xinghui Z., Furong L., Qin Z., Yun W. (2014). Internet addiction among elementary and middle school students in China: A nationally representative sample study. Cyberpsychology, Behavior, and Social Networking, 17, (02), 111-116.

Mami, S. \& Hatami-Zad, A. (2014). Investigating the effect of internet addiction on social skills and in high school students' achievement. International Journal of Social, Science $\mathcal{E}$ Education, 4 (Special Issue), 56-61

Mazuritsky, S. (2016). Compulsive internet use, empathy, and altruism. The Downside of The Web, 03, 1-11.

Melchers, M., Mei L., Yafei C., Wanqi Z., Christian M.. (2015). Low empathy is associated with problematic use of the internet: empirical evidence from China and Germany. Asian Journal of Psychiatry, 17, 56-60.

Ningtyas, S. D. Y. (2013). Hubungan antara self-control dengan internet addiction pada mahasiswa. Educational Psychology Journal, 1, (1), 25-30. 
Noorden, T. H. J. V., Willliam M. B., \& Antonius H. N. C. (2014). Empathy and involvement in bullying in children and adolescents: a systematic review. Journal of Youth and Adolescence, $44,(03), 1-22$.

Pebriana, P. H. (2017). Analisis penggunaan gadget terhadap kemampuan interaksi sosial pada anak usia dini. Jurnal Obsesi, 1, (1), 1-11.

Poli, R \& Agrimi E. (2012). Internet addiction disorder: prevalence in an Italian student population. Nordic Journal of Psychiatry, 66, 55-59.

Puspitasari, H. T. (2018). Hubungan kecanduan internet terhadap relasi sosial anak dengan orang tua. Skripsi, Program Strata 1 Universitas Muhammadiyah Surakarta, Surakarta.

Ramadhani, M. (2017). Ketergantungan ponsel bunuh rasa empati. Dari https://www.republika.co.id/berita/gaya-hidup/trend/17/06/06/or3qpj328ketergantungan-ponsel-bunuh-rasa-empati. Diakses pada 22 November 2018.

Saefulloh, A. (2018). Peran pendidik dalam penerapan internet sehat menurut islam. Jurnal Pendidikan Islam. 09, (1), 119-134.

Santrock, J. W. (2011). Perkembangan masa hidup (Ed. Tigabelas Jilid 1). Jakarta: Erlangga.

Sari, I., Martias Z., Markis Y. (2014). Meningkatkan kemampuan membaca pemahaman melalui teknik penataan gagasan bagi anak kesulitan belajar. Jurnal Ilmiah Pendidikan Khusus. 03, (4), 390-399.

Scott, K. E. \& James A. G. (2015). Service-learning implications for empathy and community engagement in elementary school children. Journal of Experimental Education, 1-19

Setyawan, W. A. N. \& T. Sulistyono. (2017). Pengaruh intensitas penggunaan handphone dan pergaulan teman sebaya terhadap motivasi belajar siswa kelas V SD se-Kecamatan Kraton Yogyakarta. Jurnal PGSD Indonesia, 03, (03), 1-10.

Shahnaz, I. \& AKM Rezaul K. (2014). The impact of internet addiction on life satisfaction and life engagement in young adults. Universal Journal Psychology, 02, (09), 273-284.

Shin, D. \& Dohyun A. (2013). Associations between game use and cognitive empathy: a crossgenerational study. Cyberpsychology, Behavior, and Social Networking, 16, (08), 599-603.

Sugiyono. (2015). Metode penelitian kuantitatif, kualitatif, dan RED. Bandung: Alfabeta.

Tahiroglu, A. Y., Gonca G. C., Mehtap U., Neslihan O., Ayse A. (2008). Internet use among Turkish Adolescent. Cyberpsychology and Behavior, 11. (05), 537-543.

Taufik. (2012). Empati pendekatan psikologi sosial. Jakarta: Raja Grafindo.

Titchener, E. B. (2014). History of mental concepts introspection and empathy. Dialogues in Phylosophy, Mental and Neuro Science, 7, (1), 25-30.

Wang, T., Ying G., Jinfu Z., Jin L., Wenbo L. (2014). The capacity for pain empathy among urban internet-addicted left-behind children in China: An event-related potential study. Computers in Human Behavior, 33, 56-62.

Wang, X., Li L., Jiping Y., Ling G., \& Fengqing Z. (2016). Moral disengagement as mediator and moderator of the relation between empathy and aggression among Chinese male juvenile delinquents. Children Psychiatry Human Development, 48, (02), 316-326.

Young, K. S. (2016). Internet addiction test. New York: Stoelting.

Young, K. S. \& Cristiano N. D. A. (2010). Internet addiction: a handbook and guide to evaluation and treatment. New York: Wiley.

Zoll, C. \& Sibylle E. (2010). A questionnaire to assess affective and cognitive empathy in children. Bamberg: Opus. 